\title{
Chemical soil attributes after wheat cropping under nitrogen fertilization and inoculation with Azospirillum brasilense
}

\section{Atributos químicos do solo após cultivo de trigo sob adubação nitrogenada e inoculação com Azospirillum brasilense}

\author{
Fernando Shintate Galindo ${ }^{1}$; Marcelo Carvalho Minhoto Teixeira Filho ${ }^{2 *}$; \\ Salatiér Buzetti²; José Mateus Kondo Santini'; João Leonardo Miranda Bellotte ${ }^{3}$; \\ Mariana Gaioto Ziolkowski Ludkiewicz'; Marcelo Andreotti²; \\ Vinicius Martins Silva ${ }^{1}$; Cássia Maria de Paula Garcia ${ }^{4}$
}

\begin{abstract}
Azospirillum brasilense plays an important role in biological nitrogen fixation (BNF) in grasses. However, further studies are needed to define how much mineral $\mathrm{N}$ can be applied while simultaneously maintaining BNF contribution and maximizing crop yield and to determine the impact of these practices on soil fertility. Thus, we aimed to investigate the effect of inoculation with $A$. brasilense, in conjunction with varying $\mathrm{N}$ doses and sources in a Cerrado soil, on soil chemical attributes after two years of irrigated wheat production. The experiment was initiated in Selvíria - MS under no-tillage production in an Oxisol in 2014 and 2015. The experimental design was a randomized block design with four replications, and treatments were arranged in a $2 \times 5 \times 2$ factorial arrangement as follows: two $\mathrm{N}$ sources (urea and Super N - urea with inhibitor of the enzyme urease NBPT (N - (n-butyl thiophosphoric triamide))), five $\mathrm{N}$ rates $\left(0,50,100,150\right.$ and $\left.200 \mathrm{~kg} \mathrm{ha}^{-1}\right)$, and with or without seed inoculation with $A$. brasilense. The increase in $\mathrm{N}$ rates did not influence the chemical soil attributes. Super $\mathrm{N}$ acidified the soil more compared to urea. A. brasilense inoculation reduced the effect of soil acidification in intensive irrigated wheat cultivation; however, the base extraction was higher, resulting in a lower soil CEC after cultivation with inoculation. Therefore, the cultivation of wheat inoculated with $A$. brasilense was not harmful to soil fertility because it did not reduce the base saturation and organic matter contents of, $\mathrm{P}$, $\mathrm{K}, \mathrm{Ca}, \mathrm{Mg}$, and $\mathrm{S}$.
\end{abstract}

Key words: Biological nitrogen fixation. No-tillage system. Soil fertility. Triticum aestivum. Urease inhibitor.

\section{Resumo}

O Azospirillum brasilense destaca-se no processo de fixação biológica de nitrogênio (FBN) em gramíneas. Contudo, mais estudos necessitam ser conduzidos para definir quanto se pode aplicar de $\mathrm{N}$ mineral considerando-se a eficiência da FBN para alcançar altas produtividades sem alterar a fixação, bem como sobre o impacto dessas práticas na fertilidade do solo. Sendo assim, objetivou-se avaliar o efeito da inoculação de trigo com A. brasilense, associada a doses e fontes de $\mathrm{N}$, em solo de Cerrado,

\footnotetext{
${ }^{1}$ Discentes, Curso de Pós-Graduação em Agronomia, Universidade Estadual Paulista, UNESP, Campus de Ilha Solteira, Ilha Solteira, SP, Brasil. E-mail: fs.galindo@yahoo.com.br; santinijmk@gmail.com; mariana.gaioto@gmail.com; vinicius-martinssilva@hotmail.com

2 Profs. Drs., UNESP, Ilha Solteira, SP, Brasil. E-mail:mcmtf@yahoo.com.br; sbuzetti@agr.feis.unesp.br; dreotti@agr.feis.unesp. br

${ }^{3}$ Eng $^{\circ}$ Agr $^{\circ}$, Eldorado Brasil, Três Lagoas, MS, Brasil. E-mail: jl.bellotte@bol.com.br

${ }^{4}$ Discente de Pós-Doutorado em Agronomia, UNESP, Ilha Solteira, SP, Brasil. E-mail: cassiampg@yahoo.com.br

* Author for correspondence
} 
avaliando-se os atributos químicos do solo após dois cultivos de trigo irrigado. O experimento foi desenvolvido em Selvíria - MS, em sistema plantio direto, em Latossolo Vermelho distrófico, em 2014 e 2015. O delineamento experimental foi o de blocos ao acaso, com quatro repetições, dispostos em um esquema fatorial 2 × 5 × 2, sendo: duas fontes de N (ureia e Super N - ureia com inibidor da enzima urease NBPT (N(-n-butil tiofosfórico triamida)); cinco doses de $\mathrm{N}$ em cobertura $(0,50,100,150$ e 200 $\left.\mathrm{kg} \mathrm{ha}^{-1}\right)$; com e sem inoculação das sementes com A. brasilense. $\mathrm{O}$ incremento das doses de $\mathrm{N}$ não influenciou os atributos químicos do solo. O Super $\mathrm{N}$ pode acidificar mais o solo comparativamente à ureia. A inoculação com A. brasilense pode reduzir o efeito da acidificação do solo em cultivos intensivos de trigo irrigado, contudo a extração de bases foi maior, refletindo em menor CTC do solo após cultivo com inoculação. Portanto, o cultivo de trigo inoculado com $A$. brasilense não é prejudicial à fertilidade do solo, pois não reduz a saturação por bases e os teores de matéria orgânica, $\mathrm{P}, \mathrm{K}, \mathrm{Ca}, \mathrm{Mg}$ e $\mathrm{S}$.

Palavras-chave: Fixação biológica de nitrogênio. Sistema plantio direto. Fertilidade do solo, Triticum aestivum. Inibidor de urease.

\section{Introduction}

In the 2015 growing season, the Brazilian area under wheat production was 2.5 million hectares, with production of 6.65 million tons and productivity of $2.68 \mathrm{t} \mathrm{ha}^{-1}$. The south region was responsible for approximately $90 \%$ of national production (CONAB, 2015). However, wheat has been introduced gradually to the Cerrado region, which has great growing potential for wheat due to its strategic position, manufacturing capacity, and climatic conditions; these conditions allow wheat to be harvested in the off-season. However, many soils cultivated with wheat in the Cerrado region and in the São Paulo State are acidic and have low fertility, which limit grain yield.

Proper nitrogen fertilization is difficult to manage; achieving high yields in cereal crops such as wheat requires large amounts of fertilizer (TEIXEIRA FILHO et al., 2014) and the adequate management of soil fertility.

Nitrogen determines the number of wheat tillers and is essential in the formation phase of the nodes and at the beginning of stretching. Therefore, $\mathrm{N}$ is the limiting nutrient in wheat yield. Plants use only approximately $50 \%$ of the nitrogen fertilizer applied, with half of the application being lost through volatilization, leaching, and denitrification. In this context, there is a possibility to increase nitrogen fertilization efficiency with the use of NBPT inhibitor (N- (n-butyl) thiophosphoric triamide), which works by inhibiting the hydrolysis of urea and significantly reducing the loss of $\mathrm{NH}_{3}$, both of which are dependent on the climatic conditions.

Among the products tested as urease inhibitors, NBPT had the best results. However, most studies conducted in Brazil have shown that combination treatments with urea and urease inhibitors and treatments with only conventional urea have the same nutritional efficiency and produce similar wheat yields (TEIXEIRA FILHO et al., 2011). This finding has not been observed in some studies that were carried out in temperate countries (CANTARELLA et al., 2008) likely because the inhibitory action of urease is not effective in reducing $\mathrm{NH}_{3}$ losses by volatilization that occur when the urea is applied to the surface of soils and because the action of NBPT depends on environmental conditions (temperature and pluvial precipitation) and the physicochemical characteristics of the soil.

Due to the large area occupied by cereal crops, BNF is extremely important, even if only part of the $\mathrm{N}$ demand can be supplied. Therefore, due to the high cost of fertilizers and the increased awareness of sustainable agriculture, the use of inoculants containing bacteria that promote plant growth and productivity might be an alternative (HUNGRIA, 2011).

In the literature, there are studies confirming that Azospirillum brasilense produces phytohormones that stimulate the growth of roots in several plant species (TIEN et al., 1979) and, consequently, improve grass nutrition in crops such as corn 
(GALINDO et al., 2016). However, in most studies with seed inoculation that show one or more benefits due to inoculation, soil fertility is generally not researched, and this understanding is relevant to subsequent crops. Moreover, studies to define how mineral $\mathrm{N}$ from conventional sources can be applied with improved efficiency in order to succeed in BNF and achieve high productivity as well as studies to analyze the effects of these combinations on soil chemical attributes have been performed.

Considering the above information, this study aimed to evaluate the effect of inoculation with $A$. brasilense, in conjunction with varying doses and sources of nitrogen, on soil chemical attributes after two consecutive years of irrigated wheat production in the Cerrado region.

\section{Material and Methods}

The experiment was conducted in an area belonging to the Faculty of Engineering - UNESP, located in Selviria - MS, with an altitude of $335 \mathrm{~m}$. The soil at the experimental site was classified as an Oxisol (Latossolo Vermelho Distroférrico) with a clay texture according to Embrapa (2013). The site was cultivated with annual crops for over 27 years. For the last 10 years, a no-tillage system was used, and the previous crop before wheat was corn, which was cultivated in both 2014 and 2015. Additionally, this area had been cultivated with only grass crops for six years. The average annual temperature was $23.5^{\circ} \mathrm{C}$, and the average annual pluvial precipitation was $1370 \mathrm{~mm}$, with annual relative air humidity averaging between 70 and $80 \%$. Figure 1 shows the climatic conditions throughout the experiment.

The experimental design was a randomized block design with four replications, and treatments were arranged in a $2 \times 5 \times 2$ factorial arrangement as follows: two $\mathrm{N}$ sources (urea and Super N - urea with inhibitor of the enzyme urease NBPT (N (n-butyl thiophosphoric triamide))), five $\mathrm{N}$ rates $(0$, 50, 100, 150 and $200 \mathrm{~kg} \mathrm{ha}^{-1}$ ), and with or without seed inoculation with $A$. brasilense.
The experimental plots were $6 \mathrm{~m}$ in length with 12 wheat rows at a spacing of $0.17 \mathrm{~m}$ between rows. The center eight rows were data rows, and excluded all rows $0.5 \mathrm{~m}$ from the ends. In the field, the herbicides glyphosate (1800 $\mathrm{g}$ active ingredient (ai) $\mathrm{ha}^{-1}$ ) and 2,4-D (670 $\mathrm{g}_{\text {ai }} \mathrm{ha}^{-1}$ ) were applied for desiccation two weeks prior to both wheat plantings. The methods proposed by Raij et al. (2001) showed the following results: $13 \mathrm{mg} \mathrm{dm}^{-3}$ of $\mathrm{P}$ (resin), $6 \mathrm{mg}$ $\mathrm{dm}^{-3}$ of $\mathrm{S}_{-} \mathrm{SO}_{4}, 23 \mathrm{~g} \mathrm{dm}^{-3}$ of organic matter (OM), $\mathrm{pH}\left(\mathrm{CaCl}_{2}\right)$ of $4.8,2.6 \mathrm{mmol}_{\mathrm{c}} \mathrm{dm}^{-3}$ of $\mathrm{K}^{+}, 13.0 \mathrm{mmol}_{\mathrm{c}}$ $\mathrm{dm}^{-3}$ of $\mathrm{Ca}^{2+}, 8.0 \mathrm{mmol}_{\mathrm{c}} \mathrm{dm}^{-3}$ of $\mathrm{Mg}^{2+}, 42.0 \mathrm{mmol}_{\mathrm{c}}$ $\mathrm{dm}^{-3}$ of $\mathrm{H}+\mathrm{Al}, 5.9 \mathrm{mg} \mathrm{dm}^{-3}$ of $\mathrm{Cu}, 30.0 \mathrm{mg} \mathrm{dm}^{-3}$ of Fe, $93.9 \mathrm{mg} \mathrm{dm}^{-3}$ of $\mathrm{Mn}, 1.0 \mathrm{mg} \mathrm{dm}{ }^{-3}$ of $\mathrm{Zn}$ (DTPA), $0.24 \mathrm{mg} \mathrm{dm}^{-3}$ of B (hot water), and $36 \%$ base saturation.

After soil chemical analysis, $2.5 \mathrm{tha}^{-1}$ of dolomitic limestone (with $88 \%$ relative total neutralizing power) was directly applied as topdressing 65 days before wheat was sown in 2014 in order to elevate the base saturation to $70 \%$ as recommended by Cantarella et al. (1997). During sowing, an 8-2816 formulation fertilizer was applied at $350 \mathrm{~kg} \mathrm{ha}^{-1}$ in both wheat plantings based on soil analysis and wheat demand.

Inoculation of wheat seeds with the bacteria $A$. brasilense AbV5 and AbV6 strains (guaranteed $2 \mathrm{x}$

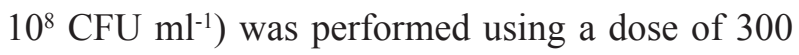
$\mathrm{ml}$ of liquid inoculant per hectare of wheat seeds with the aid of a clean cement mixer. The inoculant was mixed with the seeds one hour before the seeds were planted, in the shadow and after the seeds were treated with an insecticide.

The experiments were conducted under a notillage system in an area irrigated by a center pivot sprinkler system. The water coverage was $14 \mathrm{~mm}$ over a period of approximately $72 \mathrm{~h}$ for both crops as needed. 
Figure 1. Rainfall, air relative humidity, and maximum, average, and minimum temperature obtained from the weather station located on the Education and Research Farm of FE / UNESP during wheat cultivation in the period of May to September 2014 (A) and May to September 2015 (B).

A.

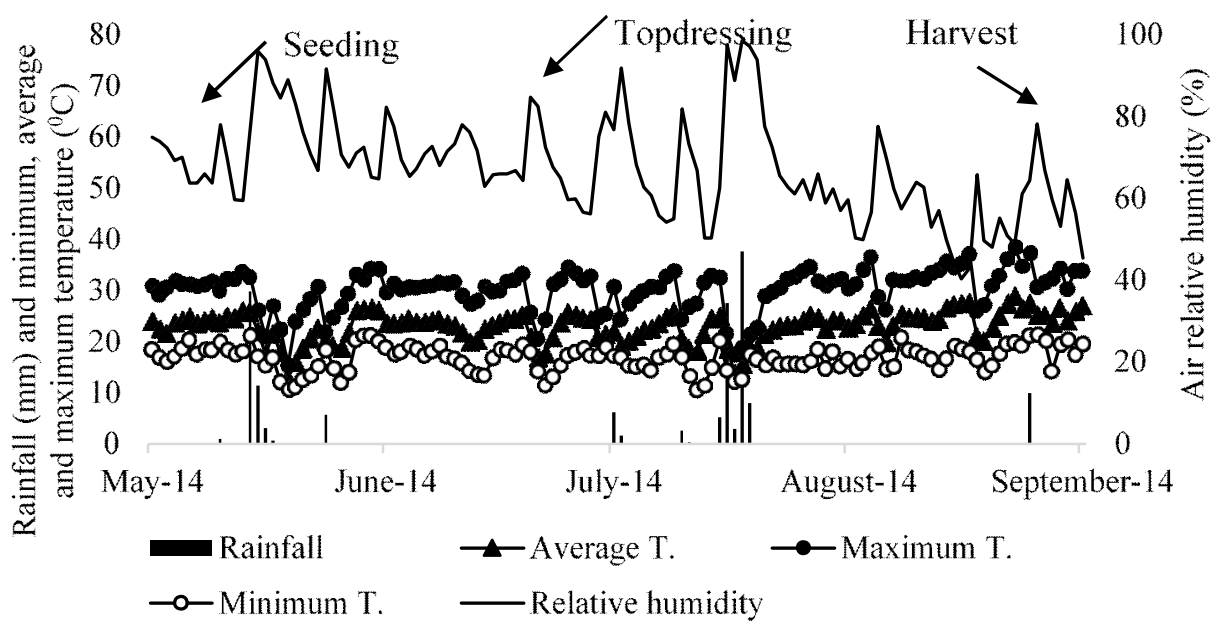

B.

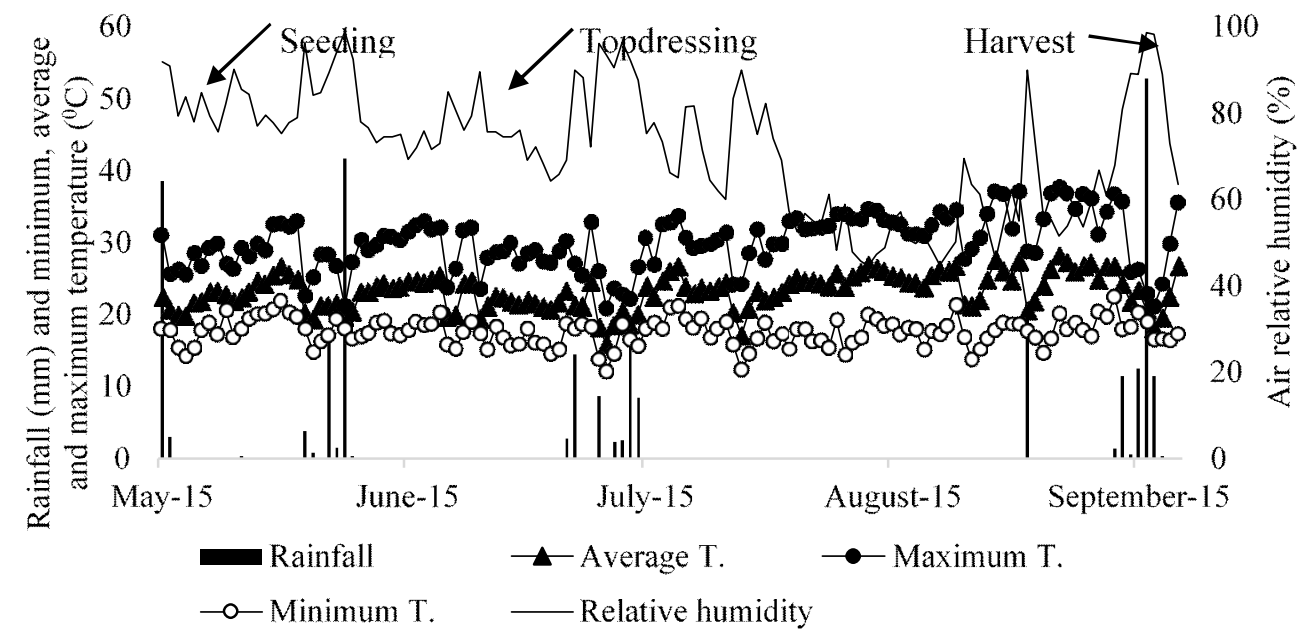

The wheat cultivar used was a CD 116 cultivar with mechanical sowing occurring on $05 / 16 / 14$ and $05 / 15 / 15$, and seedlings emerging six and five days after sowing, on days $05 / 22 / 2014$ and $05 / 20 / 2015$, respectively. Wheat was seeded at 80 seeds per meter. The seeds were treated with carbendazim + thiram fungicides $(45+105 \mathrm{~g}$ a.i. per $100 \mathrm{~kg}$ of seed) and thiodicarb + imidacloprid insecticides (45 $+135 \mathrm{~g}$ a.i. per $100 \mathrm{~kg}$ of seed).

For weed management, an application of metsulfuron methyl (3.0 $\mathrm{g} \mathrm{ha}^{-1}$ a.i.) was applied 20 days after plant emergence (DAE) for both crops. Nitrogen fertilizer topdressing was added on $06 / 26 / 2014$ and $06 / 22 / 2015$, at 35 and 32 DAE, by manually distributing the fertilizer on the soil surface (without incorporation). Fertilizer was applied to the side and approximately $8 \mathrm{~cm}$ from the rows in order to avoid plant contact with the fertilizer. Next, the topdressed area was irrigated by sprinkling (14 mm of water coverage) at night to minimize $\mathrm{N}$ losses by volatilization of $\mathrm{NH}_{3}$, which is common in irrigated wheat crops. The harvest was performed manually on 09/09/2014 and 08/09/2015 at 110 DAE. 
Soil fertility evaluations were performed soon after the crop was harvested. Soil samples were collected from a soil layer $0-0.20 \mathrm{~m}$ deep with a soil auger, with five subsamples per plot. Soil fertility evaluations determined the following: the $\mathrm{P}, \mathrm{K}$, $\mathrm{Ca}, \mathrm{Mg}, \mathrm{S}$, and organic matter (OM), $\mathrm{pH}$ in $\mathrm{CaCl}_{2}$, potential acidity $(\mathrm{H}+\mathrm{Al})$, base sum $(\mathrm{BS})$, cation exchange capacity (CEC), base saturation (V\%) and percentage of CTC occupied by $\mathrm{Ca}$ and $\mathrm{Mg}$ according to the methodology of Raij et al. (2001).

The results were subjected to analysis of variance and Tukey's test $(\mathrm{p} \leq 0.05)$ for multiple comparisons of means of $\mathrm{N}$ sources and of inoculation with or without $A$. brasilense. When the value of the F-test was significant for $\mathrm{N}$ doses, regression analyses were performed using SISVAR statistical software (FERREIRA, 2011).

\section{Results and Discussion}

The F-test values of soil chemical attributes in terms of doses and sources of $\mathrm{N}$ and inoculation with Azospirillum brasilense, in addition to the interactions between factors (doses and sources, doses and inoculation sources and inoculation and doses, sources and inoculation), are shown in Table 1.

The contents of OM, $\mathrm{P}, \mathrm{K}, \mathrm{S}, \mathrm{Ca}, \mathrm{Mg}$, percentage of CTC occupied by $\mathrm{Ca}$ and $\mathrm{Mg}, \mathrm{pH}, \mathrm{H}+\mathrm{Al}$, BS, $\mathrm{CEC}$ and $\mathrm{V} \%$ were not influenced by the increase in $\mathrm{N}$ rates (Table 2). That is, after the harvest of wheat crops in this no-tillage system, where higher doses of $\mathrm{N}$ were applied, soil acidification and reduced OM contents and nutrients were not observed.

In contrast, Lange et al. (2006) reported that nitrogen fertilization with urea initially caused an increase in $\mathrm{pH}$, especially around the granules of fertilizer. However, after the nitrification of ammonium due to urea hydrolysis, the $\mathrm{pH}$ decreased to less than the original value. According to Costa et al. (2008), acidification that is promoted by the use of nitrogen fertilizers can also change other soil chemical attributes, such as increasing exchangeable $\mathrm{Al}$ and reducing the effective $\mathrm{CEC}$ and exchangeable bases. Consequently, these changes increase the need for liming. However, these changes in soil chemical attributes were not observed in this study, which is probably because a no-tillage system was consolidated in the experimental area.

According to Malavolta (2006), in addition to nitrification, cation uptake by the roots also promotes acidification by the extrusion of $\mathrm{H}^{+}$from cells into the soil. Furthermore, according to the author, cultivation time can influence soil acidification and is likely due to the leaching and extraction of bases by plants, the exudation of organic acids by the roots, and the hydrolysis of Al, which, consequently, increases the $\mathrm{H}+\mathrm{Al}$ contents. These results have not been verified in this work but are likely because the experimental area was under a no-tillage system and was stabilized because applications of lime were applied two months before wheat was sown, and because mineral fertilization ( $\mathrm{P}$ and $\mathrm{K}$ ) was applied at planting. The no-tillage system can minimize the acidifying effects of nitrogen fertilizer by increasing the OM of the soil, which encourages the formation of amphoteric compounds that act as a buffer for soil $\mathrm{pH}$ changes and increase the ionic strength of the soil solution by increasing the exchangeable bases in the surface layer (SIQUEIRA NETO et al., 2009). 
Table 1. F-test of the contents of $\mathrm{OM}, \mathrm{P}, \mathrm{K}, \mathrm{S}, \mathrm{Ca}$ and $\mathrm{Mg}$, percentage of $\mathrm{CEC}$ occupied by $\mathrm{Ca}$ and $\mathrm{Mg}, \mathrm{pH}, \mathrm{H}+\mathrm{Al}$, base sum (BS), cation exchange capacity (CEC) and base saturation (V) in the soil after wheat crop as a function of doses and sources of N and of inoculation with Azospirillum brasilense. Selvíria - MS, 2014 and 2015.

\begin{tabular}{|c|c|c|c|c|c|c|c|c|c|c|}
\hline & \multicolumn{2}{|c|}{ OM } & \multicolumn{2}{|c|}{ P resin } & \multicolumn{2}{|c|}{$\mathbf{K}$} & \multicolumn{4}{|c|}{$\mathbf{S}$} \\
\hline & 2014 & 2015 & 2014 & 2015 & 2014 & 2015 & \multicolumn{2}{|c|}{2014} & \multicolumn{2}{|c|}{2015} \\
\hline \multicolumn{11}{|l|}{ F-test } \\
\hline D & $0.177^{\text {ns }}$ & $1.821^{\mathrm{ns}}$ & $2.298^{\mathrm{ns}}$ & $0.746^{\mathrm{ns}}$ & $1.282^{\mathrm{ns}}$ & $0.674^{\text {ns }}$ & \multicolumn{2}{|c|}{$0.577^{\mathrm{ns}}$} & \multicolumn{2}{|c|}{$0.093^{\mathrm{ns}}$} \\
\hline S & $0.036^{\mathrm{ns}}$ & $0.363^{\mathrm{ns}}$ & $0.331^{\mathrm{ns}}$ & $0.021^{\mathrm{ns}}$ & $1.290^{\mathrm{ns}}$ & $7.858^{*}$ & \multicolumn{2}{|c|}{$0.298^{\mathrm{ns}}$} & \multicolumn{2}{|c|}{$0.239^{\mathrm{ns}}$} \\
\hline I & $0.731^{\mathrm{ns}}$ & $1.620^{\mathrm{ns}}$ & $2.231^{\mathrm{ns}}$ & $1.347^{\mathrm{ns}}$ & $2.267^{\mathrm{ns}}$ & $0.238^{\mathrm{ns}}$ & \multicolumn{2}{|c|}{$0.074^{\mathrm{ns}}$} & \multicolumn{2}{|c|}{$0.027^{\mathrm{ns}}$} \\
\hline DxS & $0.335^{\text {ns }}$ & $1.328^{\mathrm{ns}}$ & $0.538^{\mathrm{ns}}$ & $2.039^{\mathrm{ns}}$ & $0.844^{\mathrm{ns}}$ & $2.237^{\mathrm{ns}}$ & \multicolumn{2}{|c|}{$0.135^{\text {ns }}$} & \multicolumn{2}{|c|}{$0.970^{\text {ns }}$} \\
\hline DxI & $0.161^{\text {ns }}$ & $1.934^{\mathrm{ns}}$ & $0.422^{\mathrm{ns}}$ & $1.400^{\mathrm{ns}}$ & $1.349^{\mathrm{ns}}$ & $0.985^{\text {ns }}$ & \multicolumn{2}{|c|}{$1.540^{\mathrm{ns}}$} & \multicolumn{2}{|c|}{$1.422^{\mathrm{ns}}$} \\
\hline SxI & $0.442^{\text {ns }}$ & $0.040^{\text {ns }}$ & $0.000^{\text {ns }}$ & $0.000^{\text {ns }}$ & $0.225^{\mathrm{ns}}$ & $0.605^{\text {ns }}$ & \multicolumn{2}{|c|}{$0.019^{\mathrm{ns}}$} & \multicolumn{2}{|c|}{$0.664^{\mathrm{ns}}$} \\
\hline \multirow[t]{3}{*}{ DxSxI } & $0.821^{\text {ns }}$ & $0.893^{\text {ns }}$ & $0.706^{\mathrm{ns}}$ & $0.617^{\mathrm{ns}}$ & $0.286^{\mathrm{ns}}$ & $1.947^{\mathrm{ns}}$ & & & 1.6 & \\
\hline & \multicolumn{2}{|c|}{ Ca } & \multicolumn{2}{|c|}{ Mg } & \multicolumn{2}{|c|}{ Ca CTC } & \multicolumn{4}{|c|}{ Mg CTC } \\
\hline & 2014 & 2015 & 2014 & 2015 & 2014 & 2015 & & & & \\
\hline \multicolumn{11}{|l|}{ F-test } \\
\hline D & $0.483^{\text {ns }}$ & $0.834^{\mathrm{ns}}$ & $0.807^{\mathrm{ns}}$ & $0.270^{\mathrm{ns}}$ & $0.074^{\mathrm{ns}}$ & $1.076^{\mathrm{ns}}$ & \multicolumn{2}{|c|}{$0.399^{\mathrm{ns}}$} & \multicolumn{2}{|c|}{$1.076^{\mathrm{ns}}$} \\
\hline S & $2.249^{\mathrm{ns}}$ & $0.268^{\mathrm{ns}}$ & $2.716^{\mathrm{ns}}$ & $1.849^{\mathrm{ns}}$ & $2.122^{\mathrm{ns}}$ & $0.299^{\text {ns }}$ & \multicolumn{2}{|c|}{$6.157^{*}$} & \multicolumn{2}{|c|}{$2.331^{\mathrm{ns}}$} \\
\hline I & $2.808^{\text {ns }}$ & $1.085^{\mathrm{ns}}$ & $1.878^{\mathrm{ns}}$ & $0.168^{\mathrm{ns}}$ & $1.620^{\mathrm{ns}}$ & $0.113^{\text {ns }}$ & & & & \\
\hline DxS & $0.568^{\mathrm{ns}}$ & $0.539^{\text {ns }}$ & $0.424^{\mathrm{ns}}$ & $0.149^{\text {ns }}$ & $0.398^{\mathrm{ns}}$ & $0.305^{\text {ns }}$ & & & 0.4 & \\
\hline DxI & $0.277^{\mathrm{ns}}$ & $1.051^{\mathrm{ns}}$ & $0.409^{\mathrm{ns}}$ & $2.363^{\mathrm{ns}}$ & $0.251^{\mathrm{ns}}$ & $1.963^{\mathrm{ns}}$ & & & 1.4 & \\
\hline SxI & $1.059^{\mathrm{ns}}$ & $0.329^{\text {ns }}$ & $1.295^{\mathrm{ns}}$ & $0.392^{\mathrm{ns}}$ & $0.259^{\text {ns }}$ & $0.016^{\text {ns }}$ & & & & \\
\hline DxSxI & $0.116^{\text {ns }}$ & $1.002^{\mathrm{ns}}$ & $0.307^{\mathrm{ns}}$ & $0.501^{\mathrm{ns}}$ & $0.562^{\mathrm{ns}}$ & $1.103^{\mathrm{ns}}$ & & & 0.3 & \\
\hline & & & & & B & & & & & \\
\hline & 2014 & 2015 & 2014 & 2015 & 2014 & 2015 & 2014 & 2015 & 2014 & 2015 \\
\hline F-test & & & & & & & & & & \\
\hline D & $0.061^{\text {ns }}$ & $1.915^{\text {ns }}$ & $0.248^{\mathrm{ns}}$ & $0.047^{\mathrm{ns}}$ & $0.544^{\mathrm{ns}}$ & $0.658^{\text {ns }}$ & $1.064^{\mathrm{ns}}$ & $0.615^{\text {ns }}$ & $0.098^{\mathrm{ns}}$ & $1.322^{\mathrm{ns}}$ \\
\hline S & $2.298^{\text {ns }}$ & $1.120^{\text {ns }}$ & $5.255^{*}$ & $2.340^{\mathrm{ns}}$ & $2.240^{\mathrm{ns}}$ & $0.001^{\text {ns }}$ & $0.992^{\mathrm{ns}}$ & $0.077^{\mathrm{ns}}$ & $4.493^{*}$ & $0.691^{\mathrm{ns}}$ \\
\hline I & $0.464^{\text {ns }}$ & $5.853^{*}$ & $0.412^{\mathrm{ns}}$ & $11.327^{* *}$ & $2.481^{\mathrm{ns}}$ & $0.529^{\text {ns }}$ & $5.262^{*}$ & $2.268^{\mathrm{ns}}$ & $0.331^{\mathrm{ns}}$ & $1.194^{\mathrm{ns}}$ \\
\hline DxS & $0.448^{\text {ns }}$ & $0.434^{\text {ns }}$ & $0.361^{\mathrm{ns}}$ & $0.197^{\mathrm{ns}}$ & $0.466^{\mathrm{ns}}$ & $0.360^{\text {ns }}$ & $0.524^{\mathrm{ns}}$ & $0.475^{\mathrm{ns}}$ & $0.340^{\text {ns }}$ & $0.126^{\mathrm{ns}}$ \\
\hline DxI & $0.882^{\mathrm{ns}}$ & $1.400^{\mathrm{ns}}$ & $0.618^{\mathrm{ns}}$ & $0.075^{\mathrm{ns}}$ & $0.389^{\text {ns }}$ & $1.571^{\mathrm{ns}}$ & $0.214^{\mathrm{ns}}$ & $0.983^{\mathrm{ns}}$ & $0.443^{\mathrm{ns}}$ & $0.419^{\mathrm{ns}}$ \\
\hline SxI & $0.631^{\mathrm{ns}}$ & $0.926^{\mathrm{ns}}$ & $0.008^{\mathrm{ns}}$ & $0.152^{\mathrm{ns}}$ & $1.205^{\mathrm{ns}}$ & $0.078^{\mathrm{ns}}$ & $1.713^{\mathrm{ns}}$ & $0.804^{\mathrm{ns}}$ & $0.367^{\mathrm{ns}}$ & $1.194^{\mathrm{ns}}$ \\
\hline DxSxI & $0.728^{\text {ns }}$ & $0.852^{\mathrm{ns}}$ & $1.634^{\mathrm{ns}}$ & $1.342^{\mathrm{ns}}$ & $0.154^{\mathrm{ns}}$ & $0.887^{\mathrm{ns}}$ & $0.924^{\mathrm{ns}}$ & $0.858^{\mathrm{ns}}$ & $0.414^{\mathrm{ns}}$ & $0.706^{\mathrm{ns}}$ \\
\hline
\end{tabular}

$* *, *$ and ns: significant at $\mathrm{p}<0.01,0.01<\mathrm{p}<0.05$, and not significant, respectively.

The results of this experiment were similar to those observed by Sarmento et al. (2008), who tested the effects of $\mathrm{N}$ doses $\left(0,150,300\right.$ and $\left.450 \mathrm{~kg} \mathrm{ha}^{-1}\right)$ on millennium grass over five years of application and found no effect of doses on $\mathrm{pH}, \mathrm{OM}, \mathrm{P}, \mathrm{K}, \mathrm{Ca}$, $\mathrm{Mg}, \mathrm{CEC}$, and $\mathrm{V} \%$ at both the beginning and end sampling periods of the experiment. In contrast,
Costa et al. (2008) studied the effects of $\mathrm{N}$ doses $\left(0,100,200\right.$ and $300 \mathrm{~kg} \mathrm{ha}^{-1}$ per year) on forage grass using urea and ammonium sulfate as sources and found that three years of nitrogen fertilization application increased the soil $\mathrm{pH}$ and $\mathrm{OM}$ as $\mathrm{N}$ doses increased. 
Table 2. Contents of OM, P, K, S, Ca and Mg, percentage of CEC occupied by $\mathrm{Ca}$ and $\mathrm{Mg}, \mathrm{pH}, \mathrm{H}+\mathrm{Al}$, base sum (BS), cation exchange capacity (CEC) and base saturation (V) in the soil after wheat crop as a function of doses and sources of N and of inoculation with Azospirillum brasilense. Selvíria - MS, 2014 and 2015.

\begin{tabular}{|c|c|c|c|c|c|c|c|c|c|c|}
\hline \multirow{2}{*}{$\begin{array}{l}\text { N doses } \\
\left(\text { kg ha }^{-1}\right)\end{array}$} & \multicolumn{3}{|c|}{$\begin{array}{c}\mathrm{OM} \\
\left(\mathrm{g} \mathrm{dm}^{-3}\right)\end{array}$} & \multicolumn{3}{|c|}{$\begin{array}{c}\text { P resin } \\
\left(\mathbf{m g ~ d m}^{-3}\right)\end{array}$} & \multicolumn{2}{|c|}{$\begin{array}{c}\mathbf{K} \\
\left(\mathbf{m m o l}_{c} \mathbf{d m}^{-3}\right)\end{array}$} & \multicolumn{2}{|c|}{$\begin{array}{c}\mathrm{S} \\
\left(\mathrm{mg} \mathrm{dm}^{-3}\right)\end{array}$} \\
\hline & 2014 & & 2015 & 2014 & 201 & & 2014 & 2015 & 2014 & 2015 \\
\hline $\mathbf{0}$ & 28.50 & & 31.75 & 23.13 & 41.2 & & 3.15 & 3.33 & 5.13 & 2.88 \\
\hline 50 & 28.63 & & 29.88 & 31.75 & 32.2 & & 3.98 & 4.06 & 5.88 & 3.00 \\
\hline 100 & 27.38 & & 29.50 & 17.50 & 32.2 & & 2.88 & 3.55 & 6.88 & 3.13 \\
\hline 150 & 28.00 & & 31.00 & 16.75 & 29.1 & & 3.00 & 3.56 & 6.00 & 3.00 \\
\hline 200 & 28.00 & & 29.00 & 21.63 & 32.2 & & 3.04 & 3.60 & 5.88 & 3.13 \\
\hline \multicolumn{11}{|l|}{ N sources } \\
\hline Urea & \multicolumn{3}{|c|}{$28.00 \mathrm{a}$} & $23.60 \mathrm{a}$ & \multicolumn{2}{|c|}{$32.90 \mathrm{a}$} & $3.41 \mathrm{a}$ & $4.02 \mathrm{a}$ & $6.15 \mathrm{a}$ & $2.95 \mathrm{a}$ \\
\hline Super $\mathbf{N}$ & \multirow{2}{*}{\multicolumn{2}{|c|}{$\begin{array}{c}28.20 \mathrm{a} \\
2.20\end{array}$}} & $30.00 \mathrm{a}$ & $20.70 \mathrm{a}$ & \multicolumn{2}{|c|}{$33.95 \mathrm{a}$} & $3.01 \mathrm{a}$ & $3.22 \mathrm{~b}$ & $5.75 \mathrm{a}$ & $3.10 \mathrm{a}$ \\
\hline L.S.D. (5\%) & & \multicolumn{2}{|c|}{2.20} & 4.96 & \multicolumn{2}{|c|}{11.82} & 0.73 & 0.47 & 1.53 & 0.64 \\
\hline \multicolumn{11}{|l|}{ Inoculation } \\
\hline With Azospirillum & \multicolumn{3}{|l|}{$27.65 \mathrm{a}$} & $20.30 \mathrm{a}$ & \multicolumn{2}{|c|}{$29.70 \mathrm{a}$} & $3.48 \mathrm{a}$ & $3.79 \mathrm{a}$ & $6.05 \mathrm{a}$ & $3.05 \mathrm{a}$ \\
\hline Without Azospirillum & $28.55 \mathrm{a}$ & \multicolumn{2}{|r|}{$30.70 \mathrm{a}$} & $24.00 \mathrm{a}$ & \multicolumn{2}{|c|}{$37.15 \mathrm{a}$} & $2.94 \mathrm{a}$ & $3.46 \mathrm{a}$ & $5.85 \mathrm{a}$ & $3.00 \mathrm{a}$ \\
\hline L.S.D. (5\%) & 2.20 & & 1.56 & 4.96 & 11.8 & & 0.73 & 0.47 & 1.53 & 0.64 \\
\hline Overall Mean & 28.10 & & 30.23 & 22.15 & 33.4 & & 3.21 & 3.62 & 5.95 & 3.03 \\
\hline C.V. (\%) & 11.84 & & 7.81 & $16.06 \#$ & $25.7^{\prime}$ & & $16.73 \#$ & 19.54 & $18.26 \#$ & $14.86 \#$ \\
\hline $\mathbf{N}$ doses $\left(\mathrm{kg} \mathrm{ha}^{-1}\right)$ & $(\mathrm{mr}$ & $\begin{array}{c}\mathrm{Ca} \\
\text { mol } \mathrm{dm}\end{array}$ & $\left.\mathbf{m}^{-3}\right)$ & $(\mathrm{mm}$ & $\mathrm{Mg}$ & & $\begin{array}{r}\mathrm{CaC} \\
(\% \\
\end{array}$ & & $\begin{array}{r}\mathrm{Mg} \\
(\%\end{array}$ & TC \\
\hline & 2014 & & 2015 & 2014 & 201 & & 2014 & 2015 & 2014 & 2015 \\
\hline $\mathbf{0}$ & 31.88 & & 1.25 & 23.75 & 27.7 & & 33.63 & 37.75 & 24.88 & 25.63 \\
\hline 50 & 27.38 & & 37.25 & 18.88 & 26.0 & & 32.50 & 37.00 & 22.38 & 25.63 \\
\hline 100 & 28.38 & & 34.63 & 20.50 & 24.0 & & 33.12 & 33.00 & 24.00 & 22.63 \\
\hline 150 & 32.13 & & 36.50 & 23.63 & 26.1 & & 34.00 & 35.75 & 24.63 & 23.38 \\
\hline 200 & 28.50 & & 36.25 & 20.38 & 25.5 & & 33.75 & 36.13 & 24.25 & 25.38 \\
\hline N sources & & & & & & & & & & \\
\hline Urea & $31.90 \mathrm{a}$ & & $38.55 \mathrm{a}$ & $23.50 \mathrm{a}$ & 27.4 & & $35.05 \mathrm{a}$ & $36.25 \mathrm{a}$ & $25.75 \mathrm{a}$ & $25.80 \mathrm{a}$ \\
\hline Super $\mathbf{N}$ & $27.40 \mathrm{a}$ & & $35.80 \mathrm{a}$ & $19.35 \mathrm{a}$ & 24.3 & & $31.75 \mathrm{a}$ & $35.60 \mathrm{a}$ & $22.30 \mathrm{~b}$ & $23.25 \mathrm{a}$ \\
\hline L.S.D. (5\%) & 5.90 & & 5.03 & 4.51 & 4.8 & & 4.11 & 2.52 & 2.91 & 2.56 \\
\hline Inoculation & & & & & & & & & & \\
\hline With Azospirillum & $26.90 \mathrm{a}$ & & $36.70 \mathrm{a}$ & $19.95 \mathrm{a}$ & 26.3 & & $32.15 \mathrm{a}$ & $36.50 \mathrm{a}$ & $23.80 \mathrm{a}$ & $26.20 \mathrm{a}$ \\
\hline Without Azospirillum & $32.40 \mathrm{a}$ & & $37.65 \mathrm{a}$ & $22.90 \mathrm{a}$ & 25.4 & & $34.65 \mathrm{a}$ & $35.35 \mathrm{a}$ & $24.25 \mathrm{a}$ & $22.85 \mathrm{~b}$ \\
\hline L.S.D. $(5 \%)$ & 5.90 & & 5.03 & 4.51 & 4.8 & & 4.11 & 2.52 & 2.91 & 2.56 \\
\hline Overall Mean & 29.65 & & 37.18 & 21.43 & 25.8 & & 33.40 & 35.93 & 24.03 & 24.53 \\
\hline C.V. (\%) & 30.06 & & 20.43 & 31.77 & 28.3 & & 18.60 & 10.60 & 18.30 & 15.80 \\
\hline $\mathbf{N}$ doses $\left(\mathrm{kg} \mathrm{ha}^{-1}\right)$ & pH (C & $\left.\mathrm{aCl}_{2}\right)$ & $\begin{array}{r}\mathrm{H}^{+} \\
(\mathrm{mmol}\end{array}$ & $\begin{array}{l}\mathrm{Al} \\
\left.\mathbf{d m}^{-3}\right)\end{array}$ & $\begin{array}{r}\mathrm{B} \\
(\mathrm{mmo}) \\
\end{array}$ & $\left.\mathrm{dm}^{-3}\right)$ & $\begin{array}{r}\mathrm{C} \\
(\mathrm{mm}\end{array}$ & $\left.\mathrm{dm}^{-3}\right)$ & (\%) & \\
\hline & 2014 & 2015 & 2014 & 2015 & 2014 & 2015 & 2014 & 2015 & 2014 & 2015 \\
\hline $\mathbf{0}$ & 5.39 & 5.51 & 33.13 & 34.50 & 58.78 & 72.60 & 91.90 & 107.10 & 61.88 & 66.63 \\
\hline 50 & 5.38 & 5.49 & 34.00 & 33.50 & 50.23 & 67.31 & 84.23 & 100.81 & 59.25 & 66.63 \\
\hline 100 & 5.41 & 5.26 & 34.13 & 41.75 & 51.75 & 62.18 & 85.88 & 103.93 & 60.25 & 59.13 \\
\hline 150 & 5.44 & 5.48 & 35.50 & 34.75 & 58.75 & 66.13 & 94.25 & 100.81 & 61.75 & 65.30 \\
\hline 200 & 5.41 & 5.39 & 32.25 & 34.50 & 51.91 & 65.14 & 84.16 & 99.64 & 61.63 & 64.81 \\
\hline $\mathbf{N}$ sources & & & & & & & & & & \\
\hline Urea & $5.49 \mathrm{a}$ & $5.46 \mathrm{a}$ & $31.30 \mathrm{~b}$ & $34.55 \mathrm{a}$ & 58.81a & $70.02 \mathrm{a}$ & $90.11 \mathrm{a}$ & $104.57 \mathrm{a}$ & $64.45 \mathrm{a}$ & $66.10 \mathrm{a}$ \\
\hline Super $\mathbf{N}$ & $5.33 \mathrm{a}$ & $5.39 \mathrm{a}$ & $36.30 \mathrm{a}$ & $37.05 \mathrm{a}$ & $49.76 \mathrm{a}$ & $63.32 \mathrm{a}$ & $86.06 \mathrm{a}$ & $100.35 \mathrm{a}$ & $57.45 \mathrm{~b}$ & $62.90 \mathrm{a}$ \\
\hline L.S.D. (5\%) & 0.18 & 0.14 & 4.57 & 3.42 & 10.52 & 9.61 & 8.50 & 7.71 & 6.91 & 4.59 \\
\hline Inoculation & & & & & & & & & & \\
\hline With Azospirillum & $5.44 \mathrm{a}$ & $5.51 \mathrm{a}$ & $33.10 \mathrm{a}$ & $33.05 \mathrm{~b}$ & $50.33 \mathrm{a}$ & $66.73 a$ & $83.43 b$ & $99.75 \mathrm{a}$ & $60.00 \mathrm{a}$ & $66.45 \mathrm{a}$ \\
\hline Without Azospirillum & $5.38 \mathrm{a}$ & $5.35 b$ & $34.50 \mathrm{a}$ & $38.55 \mathrm{a}$ & $58.25 \mathrm{a}$ & $66.62 \mathrm{a}$ & $92.74 \mathrm{a}$ & $105.17 \mathrm{a}$ & $61.90 \mathrm{a}$ & $62.55 \mathrm{a}$ \\
\hline L.S.D. (5\%) & 0.18 & 0.14 & 4.57 & 3.42 & 10.52 & 9.61 & 8.50 & 7.71 & 6.91 & 4.59 \\
\hline Overall Mean & 5.41 & 5.43 & 33.80 & 35.80 & 54.28 & 66.67 & 88.08 & 102.46 & 60.95 & 64.50 \\
\hline C.V. $(\%)$ & 5.15 & 3.85 & 20.41 & 14.43 & 29.27 & 21.77 & 14.58 & 11.37 & 17.13 & 10.76 \\
\hline
\end{tabular}

Means followed by the same letter in the column do not differ by the Tukey test at $5 \%$.

\#: data fitted by following equation $(\mathrm{x}+0.5)^{0.5}$. 
Overall, in this study, the $\mathrm{N}$ sources did not influence the soil chemical attributes except the percentage of CEC occupied by $\mathrm{Mg}, \mathrm{H}+\mathrm{Al}$ and $\mathrm{V} \%$ in 2014 and the $\mathrm{K}$ content in the soil in 2015. Urea provided a greater percentage of CEC occupied by $\mathrm{Mg}$ and $\mathrm{V} \%$ in 2014 and greater $\mathrm{K}$ content in 2015, while Super N caused higher $\mathrm{H}+\mathrm{Al}$ in the soil in 2014 (Table 2). NBPT tends to be less efficient at high temperatures due to increased urease activity, leading to a greater dissolution of the granules and, consequently, greater evaporation from the soil solution, which causes the movement of $\mathrm{NH}_{3}$ towards the surface (RAWLUK et al., 2001). With a higher concentration of $\mathrm{NH}_{3}$ at the surface and after the formation of $\mathrm{NH}_{4}^{+}$and the nitrification process, it is possible that Super $\mathrm{N}$ acidified soil more compared to urea in the surface layer. This finding may explain the reduction in the percentage of $\mathrm{Mg}$ and the increase in $\mathrm{H}+\mathrm{Al}$. However, in 2015, there were no differences between the sources numerically; Super N-treated soil was more acidic than the urea-treated soil, with the same trend as the previous crop. Another possible explanation that takes into account soils with a $\mathrm{pH}$ below 6.3 , urease catalyzes the following reaction $\mathrm{CO}\left(\mathrm{NH}_{2}\right)_{2}+2 \mathrm{H}^{+}$ $+\mathrm{H}_{2} \mathrm{O} \rightarrow 2 \mathrm{NH}_{4}+\mathrm{H}_{2} \mathrm{CO}_{3}$ and the inhibition of this reaction preserves the $\mathrm{H}^{+}$ions in the soil solution. The difference in the $\mathrm{H}+\mathrm{Al}$ values between Super $\mathrm{N}$ and urea were 5.0 and $2.5 \mathrm{mmol}_{\mathrm{c}} \mathrm{dm}^{-3}$ in 2014 and 2015, respectively.

In 2014, inoculation with $A$. brasilense influenced the soil CEC, and in 2015, inoculation with $A$. brasilense influenced the percentage of the CEC occupied by magnesium, $\mathrm{pH}$, and $\mathrm{H}$ $+\mathrm{Al}$ (Table 2). The soil CEC was amended by inoculation in 2014, where treatments that were not inoculated showed higher CEC compared to treatments that were inoculated with $A$. brasilense. The $\mathrm{BS}$ and $\mathrm{H}+\mathrm{Al}$ are the components of CEC, and in 2014, both attributes were lower when $A$. brasilense was applied, although not significantly different. However, when considered together with the $\mathrm{CEC}$, the difference was noted, and BS was more determinant due to greater uptake and export of $\mathrm{Ca}$ and $\mathrm{Mg}$ by wheat inoculated with $A$. brasilense. Although the CEC was not influenced by inoculation in 2015, numerically, the inoculated treatments had lower CEC compared to treatments that were not inoculated, following the same trend in 2014. It is noteworthy that there was no difference in the amount of BS between inoculated treatments and treatments that were not inoculated in 2015 mainly due to the fact that uptake and removal of $\mathrm{Ca}$ and $\mathrm{Mg}$ were very similar between treatments. Notably, there were no significant differences between treatments that were inoculated or not inoculated. The differences in CEC values of the un-inoculated treatments compared to the inoculated treatments were 9.31 and $5.42 \mathrm{mmol}_{\mathrm{c}} \mathrm{dm}^{-3}$, in 2014 and 2015, respectively.

In 2015, the inoculation influenced the percentage of CEC occupied by magnesium, $\mathrm{pH}$ and $\mathrm{H}+\mathrm{Al}$ in the soil, leading to a higher percentage of $\mathrm{Mg}$ in the $\mathrm{CEC}$, a higher $\mathrm{pH}$, and a lower $\mathrm{H}+\mathrm{Al}$ (Table 2). By reducing soil acidity, increasing the availability of $\mathrm{Mg}$ in $\mathrm{CEC}$, and increasing base saturation, soil fertility can be positively affected. According to Dickmann (2015), inoculation with $A$. brasilense promoted an increase in the dry weight of oat roots, indicating that inoculation promoted further development of the radicular system, allowing it to exploit a larger volume of soil, and therefore utilizing more nutrients and water, which would reduce the nutrients content and increase the acidity of the soil. However, this phenomenon was not observed in this study, even though we observed that leaves of wheat plants that were inoculated had higher levels of some nutrients, such as P (data not shown). This finding may be explained by the ability of these diazotrophic bacteria to solubilize some of the phosphate fixed in iron and aluminum oxides.

Examining the values of $\mathrm{P}, \mathrm{K}, \mathrm{Ca}, \mathrm{Mg}$ and $\mathrm{S}$ contents as well as $\mathrm{pH}$ and $\mathrm{V} \%$ values, there were average $\mathrm{P}$ and $\mathrm{S}$ contents in 2014, as well as average $\mathrm{pH}$ and $\mathrm{V} \%$ values $\left(16-40 \mathrm{mg} \mathrm{dm}^{-3} \mathrm{P} ; 5-10 \mathrm{mg} \mathrm{dm}^{-3}\right.$ of $\mathrm{S} ; \mathrm{CaCl}_{2} \mathrm{pH} 5.1-5.5,51-70 \%$ of $\mathrm{V}$, according to 
Raij et al. (1997)). For K, Ca, and Mg in the soil, the contents were high (high values: 3.1 to $6.0,>$. 7,>. $8 \mathrm{mmol}_{\mathrm{c}} \mathrm{dm}^{-3}$ of $\mathrm{K}, \mathrm{Ca}$ and $\mathrm{Mg}$, respectively, according to Raij et al. (1997). The $\mathrm{S}$ content in 2015 was low, i.e., between $0-4 \mathrm{mmol}_{\mathrm{c}} \mathrm{dm}^{-3}$ (Table $1)$, but it is noteworthy that the largest $\mathrm{S}$ content was found directly below the arable layer and that no noted deficiency was observed in wheat plants.

Another important aspect observed in this study was the average increase in OM content in the soil from 28.1 to $30.2 \mathrm{~g} \mathrm{dm}^{-3}$, an increase of $2.1 \%$ from the first crop to the second crop. This increase is high considering that most Cerrado soils where agriculture is practiced have low OM contents and that the native vegetation has been removed for decades.

In no-tillage systems, in the absence of tilling the soil, crop rotation and retention of crop residues on the surface favor aggregation that protects mineralization and promotes increased OM (CONCEIÇÃO et al., 2005). Due to increased decomposition at high temperatures, decomposition of the organic material in this research may have been effected.

In a study that examined the effect of $\mathrm{N}$ and $S$ fertilization for two years on the recovery of Brachiaria brizantha cv. Marandu pasture in a Quartzarenic Neosol, Oliveira et al. (2005) observed a decrease in the soil OM content as a function of time. It is worth noting that a pasture system with straw cannot be compared to a no-tillage system with regard to organic material and soil cover.

Pavinato and Rosolem (2008) observed that wheat grown in a no-tillage area for over 10 years resulted in increased OM content, mineralization and nutrient cycling. Additionally, these authors found that there was nutrient accumulation in the surface layers of soil in their no-tillage system likely due to the decomposition of organic material and nutrient release into the upper layers. The OM has the ability to retain nutrients, such as potassium, calcium and magnesium, and may act as a reservoir for nitrogen, phosphorus, sulfur and boron, all of which can be available to crops during their cycle.

\section{Conclusions}

The increase in $\mathrm{N}$ rates did not influence the contents of $\mathrm{OM}, \mathrm{P}, \mathrm{K}, \mathrm{Ca}, \mathrm{Mg}$ and $\mathrm{S}$, percentage of CEC occupied by $\mathrm{Ca}$ and $\mathrm{Mg}, \mathrm{pH}, \mathrm{H}+\mathrm{Al}, \mathrm{BS}, \mathrm{CEC}$ and $\mathrm{V} \%$.

Super N can acidify the soil more than urea.

Inoculation with $A$. brasilense can reduce the effect of soil acidification on irrigated wheat cultivations; however, base extraction was higher, resulting in lower soil CEC after cultivation with inoculation.

The cultivation of wheat inoculated with $A$. brasilense is not harmful to soil fertility because it does not reduce the base saturation and organic matter content ( $\mathrm{P}, \mathrm{K}, \mathrm{Ca}, \mathrm{Mg}$, and $\mathrm{S})$.

\section{References}

CANTARELLA, H.; TRIVELIN, P. O.; CONTIN, T. L. M.; DIAS, F. L. F.; ROSSETTO, R.; MARCELINO, R.; COIMBRA, R. B.; QUAGGiO, J. A. Ammonia volatilization from urease inhibitor-treated urea applied to sugarcane trash blankets. Scientia Agricola, Piracicaba, v. 65 , n. 4, p. 397-401, 2008. Available at: $<$ http://www.scielo.br/scielo.php?script=sci_arttext\&p $\mathrm{id}=\mathrm{S} 0103-90162008000400011>$. Accessed at: 13 jan. 2016.

CANTARELLA, H.; RAIJ, B. van; CAMARGO, C. E. O. Cereais. In: RAIJ, B. van; CANTARELLA, H.; QUAGGIO, J. A.; FURLANI, A. M. C. Recomendações de calagem e adubação para o Estado de São Paulo. 2. ed. Campinas: IAC, 1997. 285 p. (Boletim técnico, 100). COMPANHIA NACIONAL DE ABASTECIMENTO CONAB. Avaliação da safra agrícola 2015/2016: primeiro levantamento - outubro/2015. Brasília: CONAB, 2015. Disponível em: <http://www.conab.gov.br/OlalaCMS/ uploads/arquivos/15_10_09_17_45_57_boletim_graos _ outubro_2015_novo.pdf>. Acesso em: 12 out. 2015.

CONCEIÇÃO, P. C.; AMADO, T. J.; MIELNICZUK, J.; SPAGNOLLO, E. Qualidade do solo em sistemas de manejo avaliada pela dinâmica da matéria orgânica e atributos relacionados. Revista Brasileira de Ciência do 
Solo, Viçosa, MG, v. 9, n. 5, p. 777-788, 2005. Disponível em: $<$ http://www.scielo.br/scielo.php?script =sci_arttext \&pid $=$ S0100-06832005000500013 $>$. Acesso em: 22 out. 2015.

COSTA, K. A. P.; FAQUIN, V.; OLIVEIRA, I. P.; RODRIGUES, C.; SEVERIANO, E. C. Doses e fontes de nitrogênio em pastagem de capim-marandu. I - alterações nas características químicas do solo. Revista Brasileira de Ciência do Solo, Viçosa, MG, v. 32, n. 4, p. 1591-1599, 2008. Disponível em: <http:// www.scielo.br/scielo.php?script=sci_arttext\&pid $=$ S0100-06832008000400024 $\mathrm{P}$. Acesso em: 22 out. 2015.

DICKMANN, L. Manejo da adubação fosfatada da aveia preta e do consórcio milho/capim marandu com inoculação por Azospirillum brasilense em sistema plantio direto. 2015. Dissertação (Mestrado em Agronomia) - Universidade Estadual Paulista Júlio de Mesquita Filho, Ilha Solteira.

EMPRESA BRASILEIRA DE PESQUISA AGROPECUÁRIA - EMBRAPA. Centro Nacional de Pesquisa de Solos. Sistema brasileiro de classificação de solos. 3. ed. Brasília: EMBRAPA, 2013. 353 p.

FERREIRA, D. F. Sisvar: a computer statistical analysis system. Ciência e Agrotecnologia, Lavras, v. 35, n. 6, p. 1039-1042, 2011. Available at: <http://www.scielo. br/scielo.php?pid $=$ S1413-70542011000600001\& script $=$ sci_arttext $>$. Accessed at: 22 out. 2015.

GALINDO, F. S.; TEIXEIRA FILHO, M. C. M.; BUZETTI, S.; SANTINI, J. M. K.; ALVES, C. J.; NOGUEIRA, L. M.; LUDKIEWICZ, M. G. Z.; ANDREOTTI, M.; BELlOTTE, J. L. M. Corn yield and foliar diagnosis affected by nitrogen fertilization and inoculation with Azospirillum brasilense. Revista Brasileira de Ciência do Solo, Viçosa, MG, v. 40, e0150364, p. 1-18, 2016. Available at: <http://www. scielo.br/scielo.php?script $=$ sci_abstract\&pid $=$ S010006832016000100526\&lng=pt\&nrm =iso\&tlng=en>. Accessed at: 8 aug. 2016.

HUNGRIA, M. Inoculação com Azospirillum brasilense: inovação em rendimento a baixo custo. Londrina: Embrapa soja, 2011. 37 p. (Documentos, 325).

LANGE, A.; CARVALHO. J. L. N.; DAMIN, V.; CRUZ, J. C.; MARQUES, J. J. Alterações em atributos do solo decorrentes da aplicação de nitrogênio e palha em sistema semeadura direta na cultura do milho. Ciência Rural, Santa Maria, v. 36, n. 2, p. 460-467, 2006. Disponível em: $\quad<$ http://www.scielo.br/scielo.php? pid=S0103$84782006000200016 \&$ script=sci_arttext $>$. Acesso em: 22 out. 2015.
MALAVOLTA, E. Manual de nutrição de plantas. São Paulo: Ceres, 2006. 638 p.

OLIVEIRA, P. P. A.; TRIVALIN, P. C. O.; OLIVEIRA, W. S.; CORSI, M. Fertilização com nitrogênio e enxofre na recuperação de pastagem de Brachiaria brizantha cv. Marandu em Neossolo quartzarênico. Revista Brasileira de Zootecnia, Viçosa, MG, v. 34, n. 4, p. 1121-1129, 2005. Disponível em: <http://www.scielo.br/scielo. php?pid $=$ S1516-35982005000400005\&script $=$ sci arttext>. Acesso em: 22 out. 2015.

PAVINATO, P. S.; ROSOLEM, C. A. Disponibilidade de nutrientes no solo: decomposição e liberação de compostos orgânicos de resíduos vegetais. Revista Brasileira de Ciência do Solo, Viçosa, MG, v. 32, n. 3, p. 911-920, 2008. Disponível em: <http://www.scielo. br/scielo.php?pid=S0100-06832008000300001\&script =sci_arttext>. Acesso em: 22 out. 2015.

RAIJ, B. van; ANDRADE, J. C.; CANTARELLA, H.; QUAGGIO, J. A. Análise química para avaliação da fertilidade de solos tropicais. Campinas: IAC, 2001. 285 p.

RAIJ, B. van; CANTARELLA, H.; QUAGGIO, J. A.; FURLANI, A. M. C. Recomendações de adubação e calagem para o Estado de São Paulo. 2. ed. Campinas: IAC, 1997. 285 p. (Boletim técnico, 100).

RAWLUK, C. D. L.; GRANT, C. A.; RACZ, G. J. Ammonia volatilization from soils fertilized with urea and varying rates of urease inhibitor NBPT. Canadian Journal of Soil Science, Ottawa, v. 81, n. 2, p. 239-246, 2001. Available at: <http://pubs.aic.ca/doi/abs/10.4141/ S00-052>. Accessed at: 22 out. 2015.

SARMENTO, P.; RODRIGUES, L. R. A.; CRUZ, M. C. P.; LUGÃO, S. M. B.; CAMPOS, F. P.; CENTURION, J. F.; FERREIRA, M. E. Atributos químicos e físicos de um argissolo cultivado com Panicum maximum jacq. cv. ipr-86 milênio, sob lotação rotacionada e adubado com nitrogênio. Revista Brasileira de Ciência do Solo, Viçosa, MG, v. 32, n. 1, p. 183-193, 2008. Disponível em: <http://www.scielo.br/scielo.php?script=sci_arttext \&pid $=$ S0100-06832008000100018 $>$. Acesso em: 22 out. 2015.

SIQUEIRA NETO, M.; PICCOLO, M. C.; SCOPEL, E.; COSTA JUNIOR, C.; CERRI, C. C.; BERNOUX, M. Carbono total e atributos químicos com diferentes usos do solo no Cerrado. Acta Scientiarum. Agronomy, Maringá, v. 31, n. 4, p. 709-717, 2009. Disponível em: $<$ http://periodicos.uem.br/ojs/index.php/ ActaSciAgron/ article/view/792>. Acesso em: 22 out. 2015. 
TEIXEIRA FILHO, M. C. M.; BUZETTI, S.; ANDREOTTI, M.; ARF, O.; SÁ, M. E. de. Application times, sources and doses of nitrogen on wheat cultivars under no till in the Cerrado region. Ciência Rural, Santa Maria, v. 41, n. 8, p. 1375-1382, 2011. Available at: $\quad<$ http://www.scielo.br/scielo.php?script=sci arttext\&pid=S0103-84782011000800013\&lng=en\&nrm $=$ iso $>$. Accessed at: 23 out. 2015.
TEIXEIRA FILHO, M. C. M.; BUZETTI, S.; ANDREOTTI, M.; BENETT, C. G. S.; ARF, O.; SÁ, M. E. Wheat nitrogen fertilization under no till on the low altitude brazilian Cerrado. Journal of Plant Nutrition, Philadelphia, v. 37, n. 11, p. 1732-1748, 2014.

TIEN, T. M.; GASKINS, M. H.; HUBBELL, D. H. Plant growth substances produced by Azospirillum brasilense and their effect on the growth of pearl millet (Pennisetum americanum L.). Applied and Environmental Microbiology, Washington, v. 37, n. 5, p. 1016-1024, 1979. 
